\begin{tabular}{|l|l|}
\hline 2. To: (Receiving Organization) & 3. From: (Originating Organization) \\
Distribution & B. B. Peters/T. W. Crawford \\
\hline $\begin{array}{l}\text { 5. Proj-/Prog./Dept./Div.: } \\
\text { TWRS }\end{array}$ & $\begin{array}{l}\text { 6. Design Authority/ Design Agent/Cog. } \\
\text { Engr.: T. W. Crawford }\end{array}$ \\
\hline
\end{tabular}

8. Originator Remarks:

Approva]/Release

11. Receiver Remarks:

[] Yes [X] No

\section{Related EDT No.: \\ 7. Purchase Order No.: \\ NA}

9. Equip./Component No.:

NA

10. System/Bldg./Facility:

NA

12. Major Assm. Dwg. No.:

NA

13. Permit/Permit Application No.: NA

14. Required Response Date:

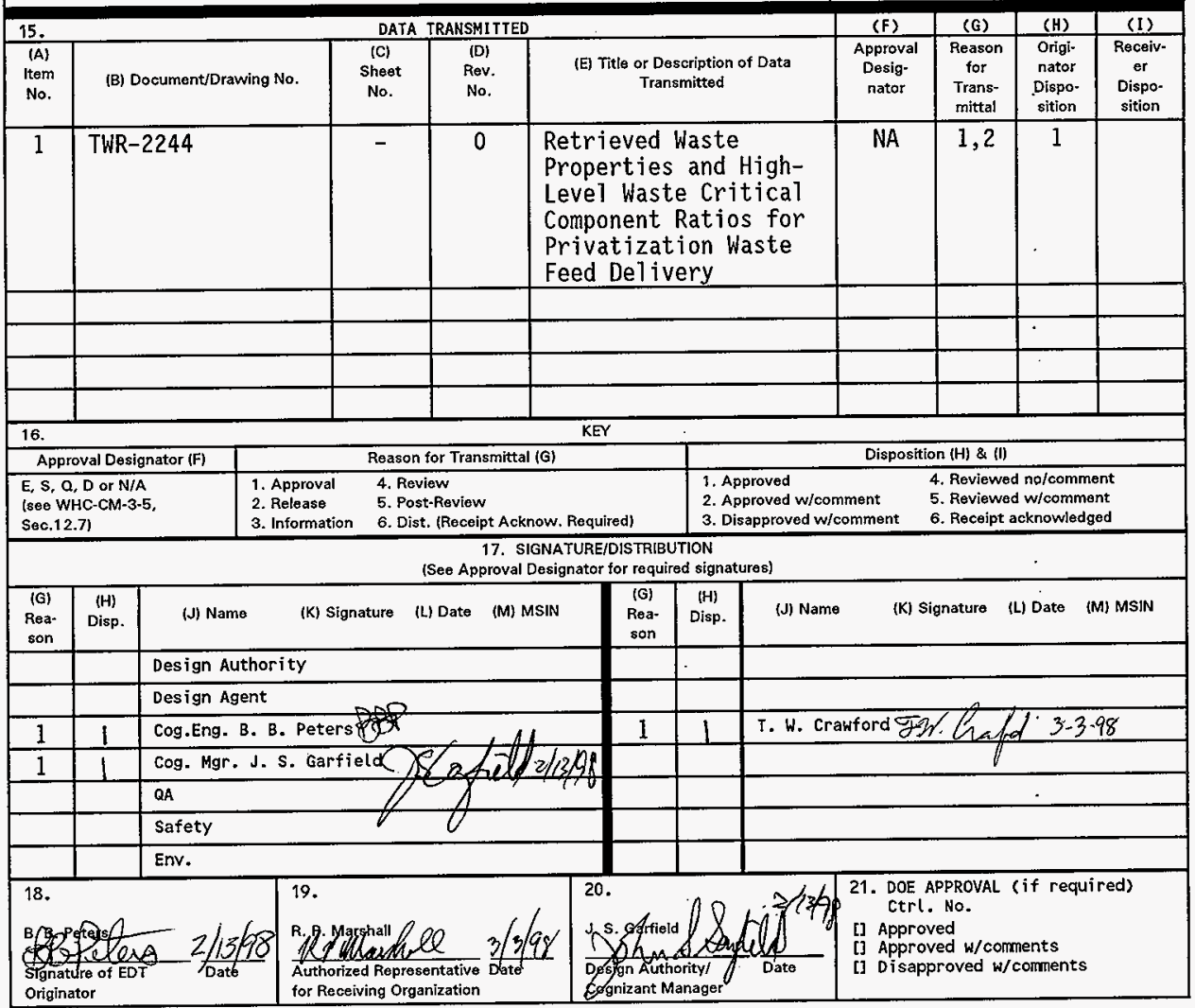




\section{Retrieved Waste Properties and High-Level Waste Critical Component Ratios for Privatization Waste Feed Delivery}

B. B. Peters (MACTEC) and T. W. Crawford

Lockheed Martin Hanford Corporation, Richland, WA 99352

U.S. Department of Energy Contract DE-AC06-96RL13200

EDT/ECN: EDT 622705 UC: 721

Org Code: 8C451 Charge Code: D2D28

B\&R Code: EW3130010 Tota1 Pages: 33

Key Words: waste properties

Abstract: The purpose for this document is to provide the basis for the retrieved waste properties and high-level waste critical component ratios specified in the System Specification for the Double-Shel.] Tank System.

TRADEMARK DISCLAIMER. Reference herein to any specific commercial product, process, or service by trade name, trademark, manufacturer, or otherwise, does not necessarily constitute or imply its endorsement, recommendation, or favoring by the United states Government or any agency thereof or its contractors or subcontractors.

Printed in the United States of America. To obtain copies of this document, contact: Document Control Services, P.0. Box 950, Mailstop H6-08, Richland WA 99352, Phone (509) 372-2420; Fax (509) 376-4989.
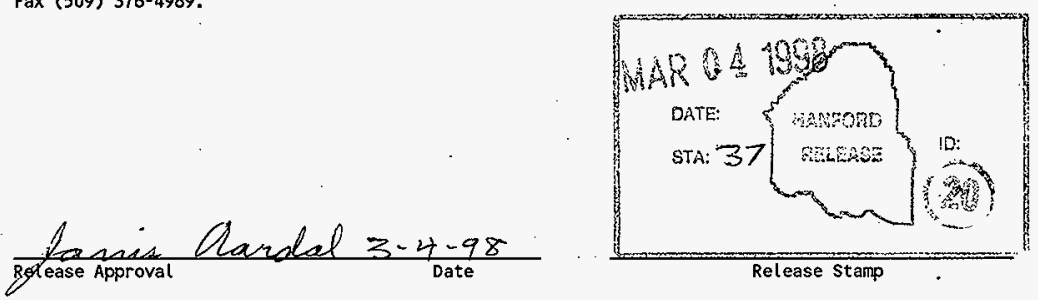


\title{
RETRIEVED WASTE PROPERTIES AND HIGH-LEVEL WASTE CRITICAL COMPONENT RATIOS FOR PRIVATIZATION WASTE FEED DELIVERY
}

February 1998

\author{
B. B. Peters \\ MACTEC \\ Richland, Washington \\ T. W. Crawford \\ Lockheed Martin Hanford Corporation \\ Richland, Washington
}

Prepared for

U.S. Department of Energy

Richland, Washington 


\section{TWR-2244}

Revision 0

This page intentionally left blank. 
1.0 INTRODUCTION $\ldots \ldots \ldots \ldots \ldots \ldots \ldots \ldots \ldots \ldots \ldots \ldots \ldots \ldots \ldots \ldots \ldots \ldots$

2.0 WASTE PROPERTIES $\ldots \ldots \ldots \ldots \ldots \ldots \ldots \ldots \ldots \ldots \ldots \ldots$

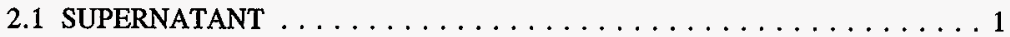

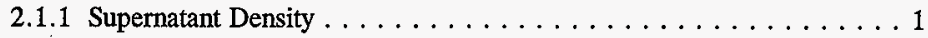

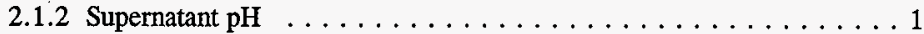

2.1.3 Supernatant Sodium Concentration $\ldots \ldots \ldots \ldots \ldots \ldots \ldots \ldots$

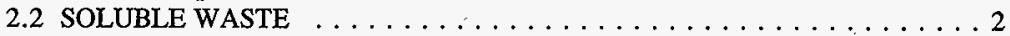

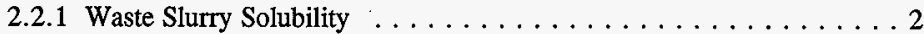

2.2.2 Soluble Waste Settled Solids Shear Strength . . . . . . . . 2

2.2.3 Soluble Waste Settled Solids In Situ Apparent Viscosity . . . . . . . . 2

2.2.4 Soluble Waste Settled Solids Yield Stress . . . . . . . . . . . 3

2.3 INSOLUBLE WASTE $\ldots \ldots \ldots \ldots \ldots \ldots \ldots \ldots \ldots \ldots \ldots \ldots$

2.3.1 Insoluble Waste Shear Strength $\ldots \ldots \ldots \ldots \ldots \ldots \ldots$

3.0 HIGH-LEVEL WASTE SLUDGE WASHING CRITICAL COMPONENT RATIOS . . 3

4.0 REFERENCES $\ldots \ldots \ldots \ldots \ldots \ldots \ldots \ldots \ldots \ldots \ldots \ldots$

APPENDIX A - SELECTED PAGES FROM CITED BASIS DOCUMENTS $\ldots . .$. A-1 
TWR-2244

Revision 0

\section{LIST OF TERMS}

DOE

HLW

TWRS

TWRSO\&UP
U.S. Department of Energy

High-level waste

Tank Waste Remediation System

Tank Waste Remediation System Operation and Utilization Plan 
TWR-2244

Revision 0

\section{RETRIEVED WASTE PROPERTIES AND HIGH-LEVEL WASTE CRITICAL COMPONENT RATIOS FOR PRIVATIZATION WASTE FEED DELIVERY}

\subsection{INTRODUCTION}

The purpose for this document is to provide the basis for the retrieved waste properties and high-level waste (HLW) critical component ratios specified in the System Specification for the Double-Shell Tank System (Grenard and Claghorn 1998).

\subsection{WASTE PROPERTES}

The system shall be capable of retrieving from double-shell tanks, during Privatization Phase 1B, wastes having the following initial properties:

\subsection{SUPERNATANT}

The waste properties provided below are only for the supernatant phase with few or no solids present.

\subsubsection{Supernatant Density}

Density: $1-1.57 \mathrm{~g} / \mathrm{mL}$

Basis: dilute transfers will be $\sim 1.0 \mathrm{~g} / \mathrm{mL}$, upper density from Tank Characterization Report for Double-Shell Tank 241-SY-101 (Herting et al. 1995).

\subsubsection{Supernatant pH}

pH: $8-14+$

Basis: A pH of 8 is the minimum allowed per Data Quality Objectives for Tank Farm Waste Compatibility Program (Mulkey 1997). Free hydroxide concentrations up to $10 \underline{M}$ (pH 14+) are specified as acceptable in Data Quality Objectives for Tank Farm Waste Compatibility Program (Mulkey 1997). 


\subsubsection{Supernatant Sodium Concentration}

Sodium: Up to 14.5 Molar

Basis: 14.5 is the soluble Na molarity of Tank AN-103 per the Tank Waste Remediation System Operation and Utilization Plan (TWRSO\&UP) (Kirkbride et al. 1997).

\subsection{SOLUBLE WASTE}

The waste properties provided below are for settled slurries produced by evaporation of dilute wastes (primarily double-shell slurry and double-shell slurry feed). These slurries consist primarily of precipitated sodium salts and tend to be highly soluble in dilute aqueous solutions.

\subsubsection{Waste Slurry Solubility}

Solubility: Assuming intimate mixing with dilution water, a majority of the soluble waste will dissolve rapidly. At dilution ratios of up to 1:1 (parts water:parts waste), the resulting solution will likely contain $<3.5 \mathrm{wt} \%$ undissolved solids. Tank 241-AN-105 dissolution kinetics tests (Herting 1997) indicate that, with intimate mixing, soluble waste dissolution occurs within 4 minutes or less. The undissolved (water insoluble) solids will typically consist of oxalate salts, silicon, chromium oxide/hydroxide, and iron oxide.

Basis: Results of Dilution Studies with Waste from Tank 241-AN-105 (Herting 1997); TWRSO\&UP (Kirkbride et al. 1997); Test Plan for Tank 241-AN-104 Dilution Studies (Herting 1998a), Test Plan for Tank 241-AW-101 Dilution Studies (Herting 1998b).

\subsubsection{Soluble Waste Settled Solids Shear Strength}

Shear Strength: $6.9 \mathrm{~Pa}$ at $300 \mathrm{~s}^{-1}$ (undiluted settled solids, $45^{\circ} \mathrm{C}$ )

$3.0 \mathrm{~Pa}$ at $300 \mathrm{~s}^{-1}$ (undiluted whole tank composite, $45^{\circ} \mathrm{C}$ )

Basis: Results of Dilution Studies with Waste from Tank 24I-AN-105 (Herting 1997).

\subsubsection{Soluble Waste Settled Solids In Situ Apparent Viscosity}

Apparent Viscosity: 10,000 to $10,000,000 \mathrm{cP}$ (in situ, unmixed)

Basis: In Situ Rheology and Gas Volume in Hanford Double-Shell Waste Tanks (Stewart et al. 1996). 
TWR-2244

Revision 0

\subsubsection{Soluble Waste Settled Solids Yield Stress}

Yield Stress: $<500 \mathrm{~Pa}$ (in situ, unmixed)

Basis: Upper value extrapolated from In Situ Rheology and Gas Volume in Hanford Double-Shell Waste Tanks (Stewart et al. 1996), Figure 5.8. Applicable to tanks 241-AN-103, 241-AN-104, 241-AN-105, 241-AW-101, and 241-SY-103.

\subsection{INSOLUBLE WASTE}

The waste properties provided below are for settled slurries usually produced by neutralization of acid waste streams generated during fuel reprocessing. The solids in these slurries are primarily metal oxides and hydroxides and are relatively insoluble in water solutions. Some components (primarily aluminum) are soluble in concentrated sodium hydroxide solutions.

\subsubsection{Insoluble Waste Shear Strength}

Shear Strength: 210 to $5360 \mathrm{~Pa}$

Basis: Shear strength of HLW sludge in tanks 241-AZ-101 and 241-AZ-102 as listed in TWRSO\&UP (Kirkbride et al. 1997), Table 3.4-10.

\subsection{HIGH-LEVEL WASTE SLUDGE WASHING CRITICAL COMPONENT RATIOS}

The system design goal is to optimize the pretreatment process, such that it provides for the greatest benefit to the U.S. Department of Energy (DOE) in terms of life-cycle cost minimization and contract compliance. Specific critical component ratios to be targeted can not be quantified at this time. They will be developed after information is received from the Privatization Contractors in their Phase 1A deliverables (e.g, Technical Reports) and the final Phase 1B contract.

The critical component ratios will then be established and the pretreatment process can be optimized to approach the targeted compositions, while remaining within contractual requirements. The critical component ratios to be targeted will be identified in the next revision of Alternatives Generation and Analysis for the Phase I High-Level Waste Pretreatment Process Selection (Manuel 1997). 
A number of HLW feed components are currently outside Envelope D specifications. After pretreatment these will be within the envelope but a number of them are expected to be near (within 20 percent) a minimum or maximum limit. These include $\mathrm{Ag}, \mathrm{Al}, \mathrm{Fe}, \mathrm{Mn}, \mathrm{Na}$, $\mathrm{Ni}, \mathrm{Pb}, \mathrm{S}, \mathrm{U}$, and $\mathrm{Zr}$. In addition, some feed components are critical in producing HLW glass but due to their expected concentrations do not approach Envelope D limits. These components include $\mathrm{B}, \mathrm{Ca}, \mathrm{Cr}, \mathrm{K}, \mathrm{Li}$, and $\mathrm{Mg}$. Several radionuclides including ${ }^{241} \mathrm{Am},{ }^{137} \mathrm{Cs}$, ${ }^{60} \mathrm{Co},{ }^{154} \mathrm{Eu},{ }^{155} \mathrm{Eu},{ }^{239} \mathrm{Pu},{ }^{241} \mathrm{Pu},{ }^{106} \mathrm{Ru}$, and ${ }^{90} \mathrm{Sr}$ are critical to determine gamma and neutron dose rates for operations in the vitrification facility and for the product canisters. 
TWR-2244

Revision 0

\subsection{REFERENCES}

DOE-RL, 1996, TWRS Privatization Request for Proposals, Solicitation DE-RP06-96RL13308, U.S. Department of Energy, Richland, Washington.

Grenard, C. E., and R. D. Claghorn, 1998, System Specification for the Double-Shell Tank System, HNF-SD-WM-TRD-007, Rev. C, Numatec Hanford Corporation, Richland, Washington.

Herting, D. L., T. L. Welsh, R. W. Lambie, T. T. Tran, 1995, Tank Characterization Report for Double-Shell Tank 241-SY-101, WHC-SD-WM-ER-409, Rev. 0, Westinghouse Hanford Company, Richland, Washington.

Herting, D. L., 1997, Results of Dilution Studies With Waste From Tank 241-AN-105, HNF-SD-WM-DTR-046, Rev. 0, Numatec Hanford Corporation, Richland, Washington.

Herting, D. L., 1998a, Test Plan for Tank 241-AN-104 Dilution Studies, HNF-1863, Rev. 0, Numatec Hanford Corporation, Richland, Washington.

Herting, D. L., 1998b, Test Plan for Tank 241-AW-101 Dilution Studies, HNF-2239, Rev. 0, Numatec Hanford Corporation, Richland, Washington.

Kirkbride, R. A., G. K. Allen, P. J. Certa, A. F. Manuel, R. M. Orme, L. W. Shelton, E. J. Slaathaug, R. S. Wittman, and G. T. Maclean and D. L. Penwell (SESC), 1997, Tank Waste Remediation System Operation and Utilization Plan, HNF-SD-WM-SP-012, Rev. 0, Vol. I and II, Numatec Hanford Corporation, Richland, Washington.

Manuel, A. F., 1997, Alternatives Generation and Analysis for the Phase I High-Level Waste Pretreatment Process Selection, HNF-SD-TWR-AGA-003, Rev. 0, Numatec Hanford Corporation, Richland, Washington.

Mulkey, C. H., 1997, Data Quality Objectives for Tank Farms Waste Compatibility Program, HNF-SD-WM-DQO-001, Rev 2, Lockheed Martin Hanford Corporation, Richland, Washington.

Stewart, C. W., J. M. Alzheimer, M. E. Brewster, G. Chen, R. E. Mendoza (WHC), H. C. Reid, C. L. Shepard, and G. Terrones, 1996, In Situ Rheology and Gas Volume In Hanford Double-Shell Waste Tanks, PNNL-11296, Rev. 0, Pacific Northwest National Laboratory, Richland, Washington. 
TWR-2244

Revision 0

This page intentionally left blank. 


\section{APPENDIX A}

\section{SELECTED PAGES FROM CITED BASIS DOCUMENTS}

- Tank Waste Remediation System Operation and Utilization Plan (Kirkbride et al. 1997), pages A-3 through A-5

- Data Quality Objectives for Tank Farms Waste Compatibility Program (Mulkey 1997), pages A-6 through A-7

- TWRS Privatization Request for Proposals (DOE-RL 1996), pages A-8 through A-9

- Results of Dilution Studies With Waste From Tank 241-AN-105 (Herting 1997), pages A-10 through A-14

- In Situ Rhelology and Gas Volume In Hanford Double-Shell Waste Tanks (Stewart et al. 1996) pages A-15 through A-21. 
TWR-2244

Revision 0

This page intentionally left blank. 

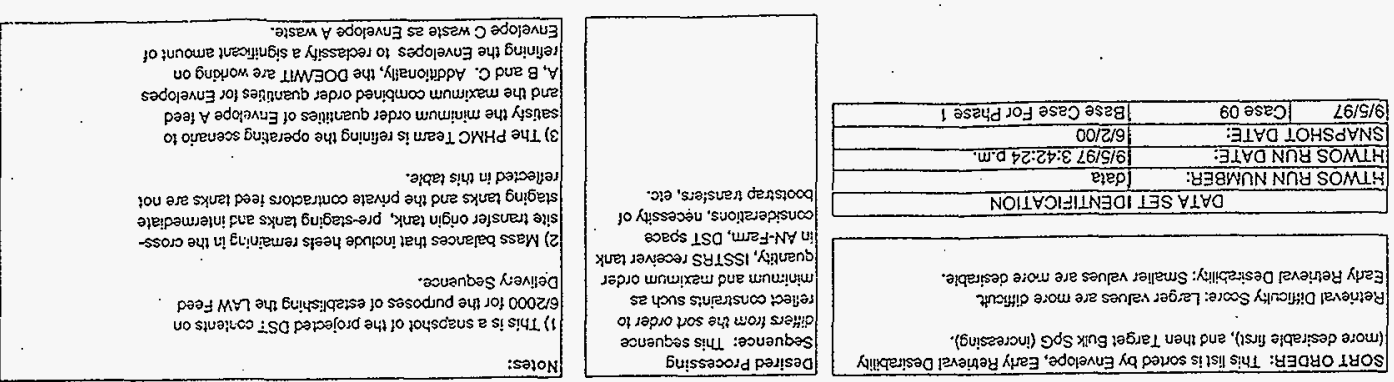

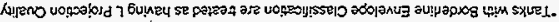
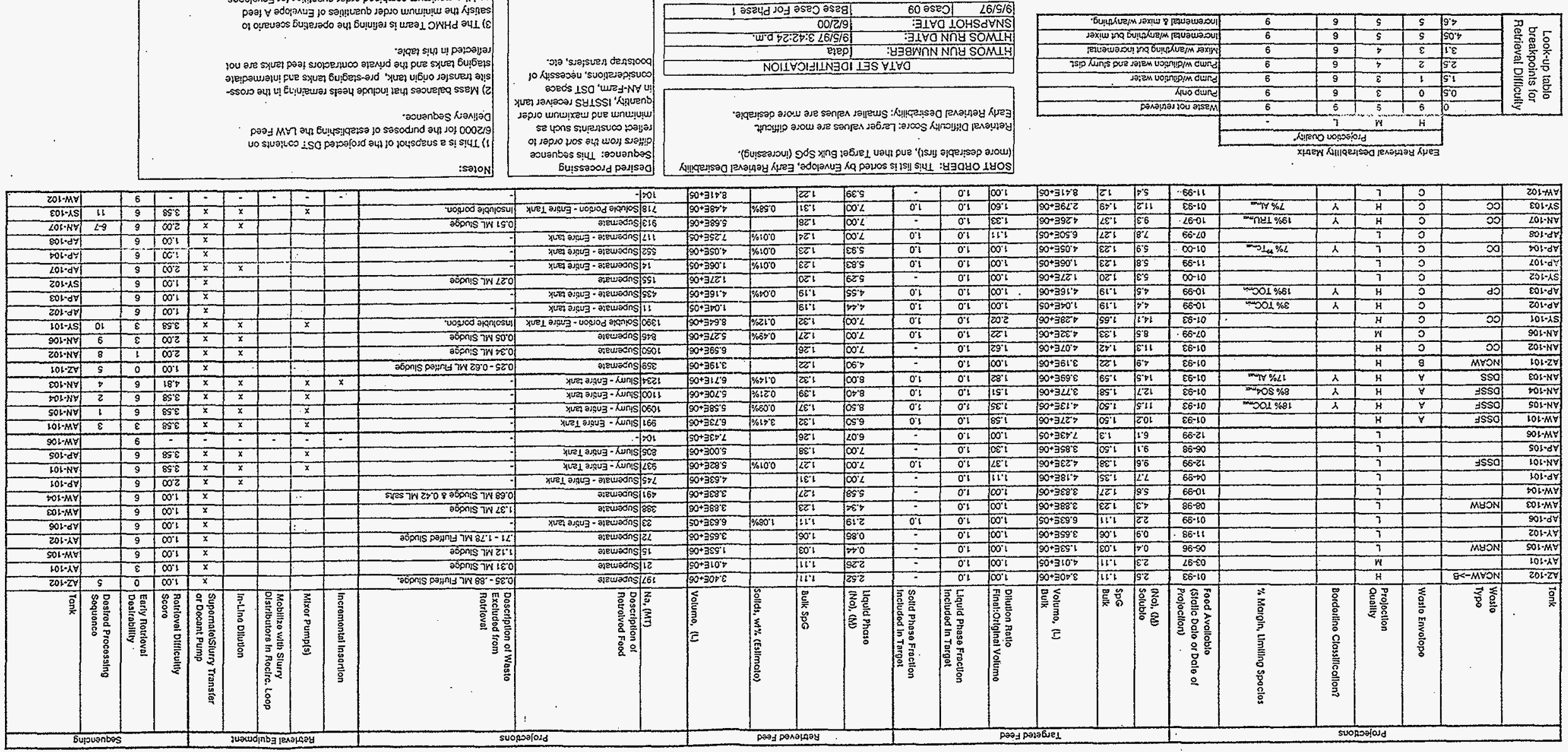

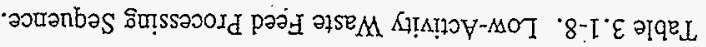




$\begin{array}{cc}r \text { f. HNF-SD-WM-SP-012 } & \text { TWR-2244 } \\ \text { Revision 0 } & \text { Revision 0 }\end{array}$

Table 3.4-10. Shear Strength of Phase I Sludges.

\begin{tabular}{|c|c|c|}
\hline Sample & $\begin{array}{c}\text { Shear strength } \\
\left.\text { (dynes } / \mathrm{cm}^{2}\right)\end{array}$ & $\begin{array}{l}\text { Temperature } \\
\left({ }^{\circ} \mathrm{C}\right)\end{array}$ \\
\hline $\begin{array}{c}\text { 241-AY-102 } \\
\text { Segment } 1 \mathrm{R} \text { top } \\
\text { Segment } 1 \mathrm{R} \text { middle } \\
\text { Segment } 1 \mathrm{R} \text { bottom }\end{array}$ & $\begin{array}{r}53,600 \\
16,700 \\
21,700 \\
\end{array}$ & $\begin{array}{l}35 \\
35 \\
35 \\
\end{array}$ \\
\hline $\begin{array}{c}241-A Z-101 \\
\text { First Core Sample }\end{array}$ & 2,100 and 2,600 & 28 and 28 \\
\hline $\begin{array}{c}\text { 241-AZ-101 } \\
\text { Second Core Sample }\end{array}$ & $15,000^{\circ}$ & 30 \\
\hline $\begin{array}{c}241-\mathrm{AZ}-102 \\
\text { Segment } 1\end{array}$ & 15,400 and 13,140 & 31 and 31 \\
\hline $\begin{array}{c}241-A Z-102 \\
\text { Segment } 2\end{array}$ & $i$ & 31 \\
\hline
\end{tabular}

Table 3.4-11. Effective Cleaning Radius and Mobilization Using Two Mixer Pumps.

\begin{tabular}{|c|c|c|}
\hline $\begin{array}{c}\text { Shear strength } \\
\left(\text { dynes } / \mathrm{cm}^{2}\right)\end{array}$ & $\begin{array}{c}\text { Effective cleaning radius } \\
(\mathrm{m})\end{array}$ & \% mobilized \\
\hline 7,000 & 12.5 & 99 \\
\hline 14,000 & 7.9 & 75 \\
\hline 28,000 & 4.9 & 36 \\
\hline 70,000 & 2.7 & 11 \\
\hline
\end{tabular}

A composite of the second 241-AZ-101 core was analyzed on the Brinkman Model 2010 particle size analyzer (1) as-is, and (2) after washing. Table 3.4-12 shows the mean particle diameter on a volume and population basis. There was essentially no difference between unwashed and washed solids. The Brinkman instrument registered few 241-AZ-101 particles bigger than 13 microns, and 90 percent (by population) were less than 2 microns. The same samples were analyzed again after six weeks, yielding essentially the same results. 


\subsection{CORROSION}

\subsection{PROBLEM/QUESTION}

The following question posed by the decision makers was discussed and accepted.

Will any transfer increase corrosion in pipes and tanks?

Both $\mathrm{DOE}$ and Ecology have acknowledged that corrosion in pipes occurs. Both parties agree on the need to control corrosion in the tanks. Both parties disagree on the meaning of "increase." Ecology has indicated that increase means "increase beyond a minimal value based on best avaijable technology." "The DOE has indicated that increase means from current corrosion rates.

The result is that the two parties have not agreed upon the need to implement treated flush water after transfers. The DOE and Ecology have agreed on the following tank corrosion specifications to mitigate corrosion in the tanks.

\subsection{INPUTS}

The established inputs to evaluate corrosion potential for all tanks and piping systerns are hydroxide $\left[\mathrm{OH}^{-}\right]$, nitrate $\left[\mathrm{NO}_{3}^{-}\right]$, and nitrite $\left[\mathrm{NO}_{2}^{-}\right]$. Inputs are slightly different for tanks depending upon the temperature, $\mathrm{T} \leq 100^{\circ} \mathrm{C}\left(212^{\circ} \mathrm{F}\right)$ and $\mathrm{T}>100^{\circ} \mathrm{C}\left(212^{\circ} \mathrm{F}\right)$.

\subsubsection{Tank Composition}

$$
\begin{aligned}
& \text { Temperatures }\left(\mathrm{T} \leq 100^{\circ} \mathrm{C}\left(212^{\circ} \mathrm{F}\right)\right) \text {. } \\
& \text { Yariable } \\
& \text { Specification Limit } \\
& \text { [OH] } \\
& {\left[\mathrm{NO}_{2}^{-}\right]} \\
& {\left[\mathrm{NO}_{3}\right] /\left(\left[\mathrm{OH}^{-}\right]+\left[\mathrm{NO}_{2}^{-}\right]\right)} \\
& 0.010 \mathrm{M} \leq[\mathrm{OH}] \leq 5.0 \mathrm{M} \\
& 0.011 \mathrm{M} \leq\left[\mathrm{NO}_{2}\right] \leq 0.5 \mathrm{M} \\
& <2,5
\end{aligned}
$$

(For solutions below $75^{\circ} \mathrm{C}\left(167^{\circ} \mathrm{F}\right)$, the $[\mathrm{OH}]$ maximum limit is $8.0 \mathrm{M}$ )

For $1.0 \mathrm{M}<\left[\mathrm{NO}_{3}{ }^{-}\right] \leq 3.0 \mathrm{M}$ :

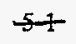




$$
\begin{gathered}
{\left[\mathrm{OH}^{-}\right]} \\
{\left[\mathrm{OH}^{-}\right]+\left[\mathrm{NO}_{2}^{-}\right]} \\
\text {For }\left[\mathrm{NO}_{3}^{-}\right]>3.0 \mathrm{M}: \\
{\left[\mathrm{OH}^{-}\right]} \\
{\left[\mathrm{OH}^{-}\right]+\left[\mathrm{NO}_{2}^{-}\right]} \\
{\left[\mathrm{NO}_{3}^{-}\right]}
\end{gathered}
$$

For high operating temperatures $\left(\mathrm{T}>100^{\circ} \mathrm{C}\left(212^{\circ} \mathrm{F}\right)\right.$ for $\mathrm{AY}$ and $\mathrm{AZ}$ tanks), the previously stated limits apply with the exception that [OH] must be $<4 \mathrm{M}$.

\subsubsection{Inpat Basis for Hydroxide, Nitrite, Nitrate}

The failure mechanisms are outlined to allow understanding of the concentration of the ions that prevent corrosion. Premature faihure of carbon steel components in hot nitrate solutions can be caused by stress corrosion cracking (SCC): In the absence of residual stresses approaching yield strength, failure of carbon steel components can still occur by pitting. At the Savannah River Site (SRS), SCC occurred in non-stress relived tanks. The non-stress relieved catbon steel waste tanks also contained waste with hydroxide and nitrite compositions outside the specification limits leading to SCC. Similar failures were also noted at the Hanford Site in the SSTs. These failures have also been attributed to SCC caused by nitrate (Anantatmula et al. 1994). Based on laboratory experiments, waste composition specifications were developed at the SRS (Ondrejcin et al. 1979) that would mitigate accelerated corrosion of carbon steel by pitting and SCC in SRS wastes. Because of the similarities between the waste comp ositions, the tank steel types and the operating conditions at the Hanford Site and SRS, it was recommended that the corrosion specifications in use at the SRS be used at the Hanford Site (Moore 1979) for the DSTs. The technical basis document for waste tank corrosion specifications (Kirch 1984) lists the concentration ranges of hydroxide and nitrite telative to nitrate in waste solutions. The concentrations listed result in waste solutions that are not corrosive to tank steel and waste transfer equipment. The DSTs were stress relieved and, thus far, no failures have been observed. in the Hanford Site DSTs. Additional substantiation of limits when nitrate is $\angle 1.0 \mathrm{M}$, is found in Darielson and Burnell (1994).

The presence of adequate concentrations of hydroxide and nitrate and using correct ratios of these anions prevents pitting/SCC of carbon steel. The inputs in Section 5.2.1 are from SD-WM-TI150, Technical Basis for Waste Tank Corrosion Specifications (Kirch 1984), AC-EP-0772, Characterization of the Corrosion Behavior of the Carbon Steel Liner in Hanford Single-Shell Tanks (Anantatmula et a1. 1994), and TWRS-PP-94-025, Sludge Washing Materials Study: The Behavior of Carbon Steel in a Dilute Waste Environment (Danielson and Bumell 1994). The nitrite, nitrate, and hydroxide concentrations are controlled in order to inbibit accelerated uniform 
Table TS-7.1 LAW Chemical Composition (Continued)

\begin{tabular}{|c|c|c|c|}
\hline \multirow{2}{*}{$\begin{array}{c}\text { Chemical } \\
\text { Analyte }\end{array}$} & \multicolumn{3}{|c|}{ Maximum Ratio, analyte (mole) to sodium (mole) } \\
\cline { 2 - 4 } & Envelope A & Envelope B & Envelope C \\
\hline \hline $\mathrm{OH}$ & $7.0 \mathrm{E}-01$ & $7.0 \mathrm{E}-01$ & $7.0 \mathrm{E}-01$ \\
\hline $\mathrm{Pb}$ & $6.8 \mathrm{E}-04$ & $6.8 \mathrm{E}-04$ & $6.8 \mathrm{E}-04$ \\
\hline $\mathrm{PO}_{4}$ & $3.8 \mathrm{E}-02$ & $1.3 \mathrm{E}-01$ & $3.8 \mathrm{E}-02$ \\
\hline $\mathrm{SO}_{4}$ & $9.7 \mathrm{E}-03$ & $7.0 \mathrm{E}-02$ & $2.0 \mathrm{E}-2$ \\
\hline $\mathrm{TIC}$ & $3.0 \mathrm{E}-01$ & $3.0 \mathrm{E}-01$ & $3.0 \mathrm{E}-01$ \\
\hline $\mathrm{TOC}^{1}$ & $6.0 \mathrm{E}-02$ & $6.0 \mathrm{E}-02$ & $5.0 \mathrm{E}-01$ \\
\hline$U$ & $1.2 \mathrm{E}-03$ & $1.2 \mathrm{E}-03$ & $1.2 \mathrm{E}-03$ \\
\hline
\end{tabular}

Note:

1 For each atom of Carbon in TOC.

Table TS-7.2 LAW Radionuclide Content

\begin{tabular}{|c|c|c|c|}
\hline \multirow{4}{*}{ Radionuclide } & \multicolumn{3}{|c|}{ Maximum Ratio, radionuclide (Bq) to sodium (mole) } \\
\cline { 2 - 4 } & Envelope A & Envelope B & Envelope C \\
\hline \multirow{2}{*}{ TRU } & $4.8 \mathrm{E}+05$ & $4.8 \mathrm{E}+05$ & $3.0 \mathrm{E}+06$ \\
\cline { 2 - 4 } & $4.3 \mathrm{E}+09$ & $6.0 \mathrm{E}+10$ & $4.3 \mathrm{E}+09$ \\
\cline { 2 - 4 } & ${ }^{137} \mathrm{Cs}$ & $4.4 \mathrm{E}+07$ & $8.0 \mathrm{E}+08$ \\
${ }^{90} \mathrm{Sr}$ & $4.4 \mathrm{E}+07$ & $7.1 \mathrm{E}+06$ & $7.1 \mathrm{E}+06$ \\
\hline
\end{tabular}

Notes:

1 Some radionuciides, such as ${ }^{\infty} \mathrm{Sr}$ and ${ }^{139} \mathrm{Cs}$. have daughters with relatively short half-lives. These daughters have not been listed in this table. However, they are present in concentrations associated with the normal decay chains of the radionuclides. 


\section{Specification 7: Low-Activity Waste Envelopes Definition}

7.1 Scope: This Specification establishes three waste envelopes for Low-Activity Waste (LAW) services: Waste Envelopes A, B, and C. Each waste envelope provides the compositional range of chemical and radioactive constituents in the waste feed to be treated.

7.2 Composition: This specification lists the concentration limits for the LAW Envelopes A, B, and C feed to be transferred by DOE to the Contractor for LAW services. The waste feed will be delivered with a sodium concentration between $3 \mathrm{M}$ and $14 \mathrm{M}$. The insoluble solids fraction will not exceed 5 volume \% of the waste transferred as Waste Envelopes A; B, and C. Trace quantities of radionuclides, chemicals, and other impurities may be present in the waste feed. All feed provided will meet the Tank Farm Operations specifications given in OSD-T-151-00007.

Table TS-7.1.LAW Chemical Composition

\begin{tabular}{|c|c|c|c|}
\hline \multirow{2}{*}{$\begin{array}{c}\text { Chemical } \\
\text { Analyte }\end{array}$} & \multicolumn{3}{|c|}{ Maximum Ratio, analyte (mole) to sodium (mole) } \\
\cline { 2 - 4 } & Envelope A & Envelope B & Envelope C \\
\hline $\mathrm{Al}$ & $1.9 \mathrm{E}-01$ & $1.9 \mathrm{E}-01$ & $1.9 \mathrm{E}-01$ \\
\hline $\mathrm{Ba}$ & $1.0 \mathrm{E}-04$ & $1.0 \mathrm{E}-04$ & $1.0 \mathrm{E}-04$ \\
\hline $\mathrm{Ca}$ & $4.0 \mathrm{E}-02$ & $4.0 \mathrm{E}-02$ & $4.0 \mathrm{E}-02$ \\
\hline $\mathrm{Cd}$ & $4.0 \mathrm{E}-03$ & $4.0 \mathrm{E}-03$ & $4.0 \mathrm{E}-03$ \\
\hline $\mathrm{Cl}$ & $3.7 \mathrm{E}-02$ & $.98 \mathrm{E}-02$ & $3.7 \mathrm{E}-02$ \\
\hline $\mathrm{Cr}$ & $6.9 \mathrm{E}-03$ & $2.0 \mathrm{E}-02$ & $6.9 \mathrm{E}-03$ \\
\hline $\mathrm{F}$ & $9.1 \mathrm{E}-02$ & $2.0 \mathrm{E}-01$ & $9.1 \mathrm{E}-02$ \\
\hline $\mathrm{Fe}$ & $1.0 \mathrm{E}-02$ & $1.0 \mathrm{E}-02$ & $1.0 \mathrm{E}-02$ \\
\hline $\mathrm{Hg}$ & $1.4 \mathrm{E}-05$ & $1.4 \mathrm{E}-05$ & $1.4 \mathrm{E}-05$ \\
\hline $\mathrm{K}$ & $1.8 \mathrm{E}-01$ & $1.8 \mathrm{E}-01$ & $1.8 \mathrm{E}-01$ \\
\hline $\mathrm{La}$ & $8.3 \mathrm{E}-05$ & $8.3 \mathrm{E}-05$ & $8.3 \mathrm{E}-05$ \\
\hline $\mathrm{Ni}$ & $3.0 \mathrm{E}-03$ & $3.0 \mathrm{E}-03$ & $3.0 \mathrm{E}-03$ \\
\hline $\mathrm{NO}$ & $3.8 \mathrm{E}-01$ & $3.8 \mathrm{E}-01$ & $3.8 \mathrm{E}-01$ \\
\hline $\mathrm{NO}$ & $8.0 \mathrm{E}-01$ & $8.0 \mathrm{E}-01$ & $8.0 \mathrm{E}-01$ \\
\hline
\end{tabular}


TWR-2244

Revision 0

HNF-SD-WM-DTR-046, Rev. D

Figure 7-1. Tank Waste Volumes and Sodium Inventories as a Function of Dilution

\section{WTC Samples}

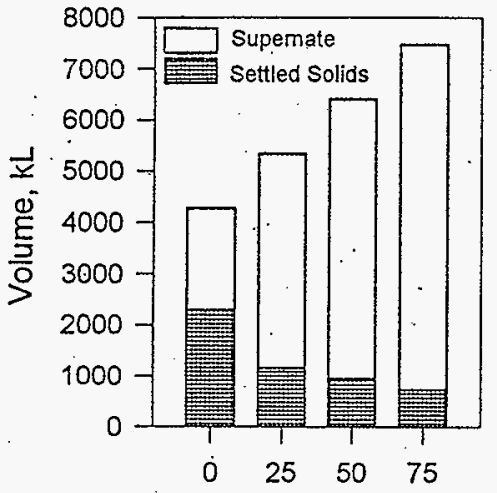

Dilution, Volume Percent

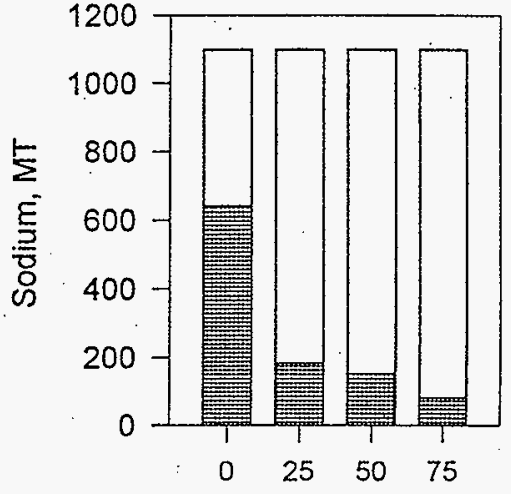

Dilution, Volume Percent

\section{Settled Solids Samples}

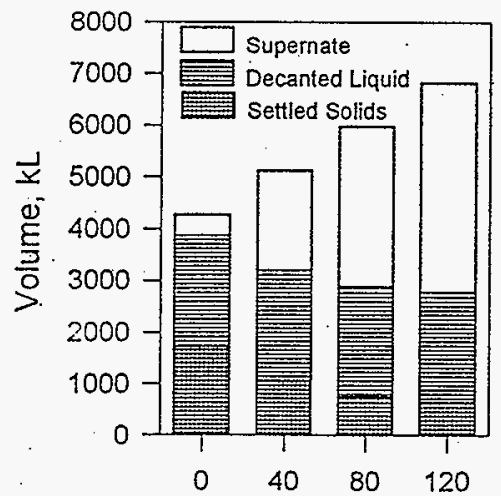

Dilution, Volume Percent

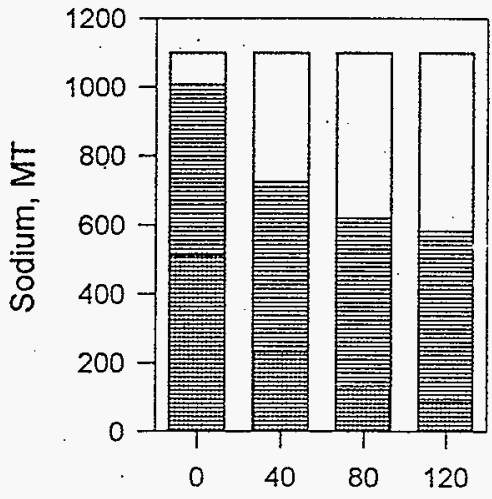

Dilution, Volume Percent 
TWR-2244

Revision 0

wef. HMF-SD-LM-DTR-046-REV.O

$8 C 510-97-028$

At tachment XII

VISCOSITY ANALYSIS OF UNDILUTED SETTLED SOLIDS

AT APPROXIMATELY $45^{\circ} \mathrm{C}$

Consisting of 7 Pages incluoding the cover page 
.$\quad$.

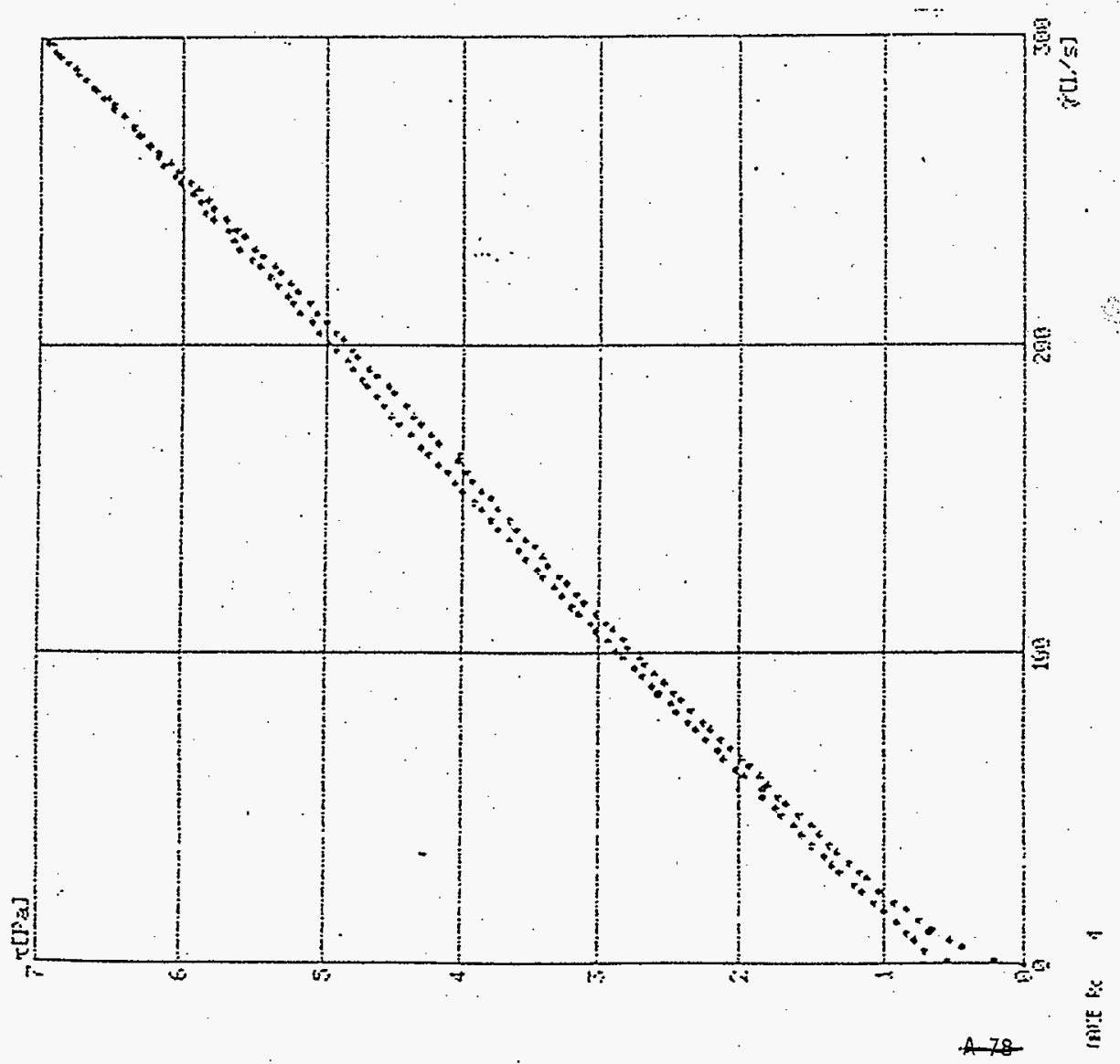


TWR-2244

Revision 0

reff HAF-SD-WS-DTR-046-REV.O

\section{$8 C 510-97-028$}

Attachment VI

VISCOSITY ANALYSIS OF UNDILUTED WHOLE TANK COMPOSITE AT APPROXIMATELY $45^{\circ} \mathrm{C}$

Consisting of 7 Pages including the cover page 
TWR-2244

Revision 0

Neft KNF-SD-LW-DTR-046-REV.O

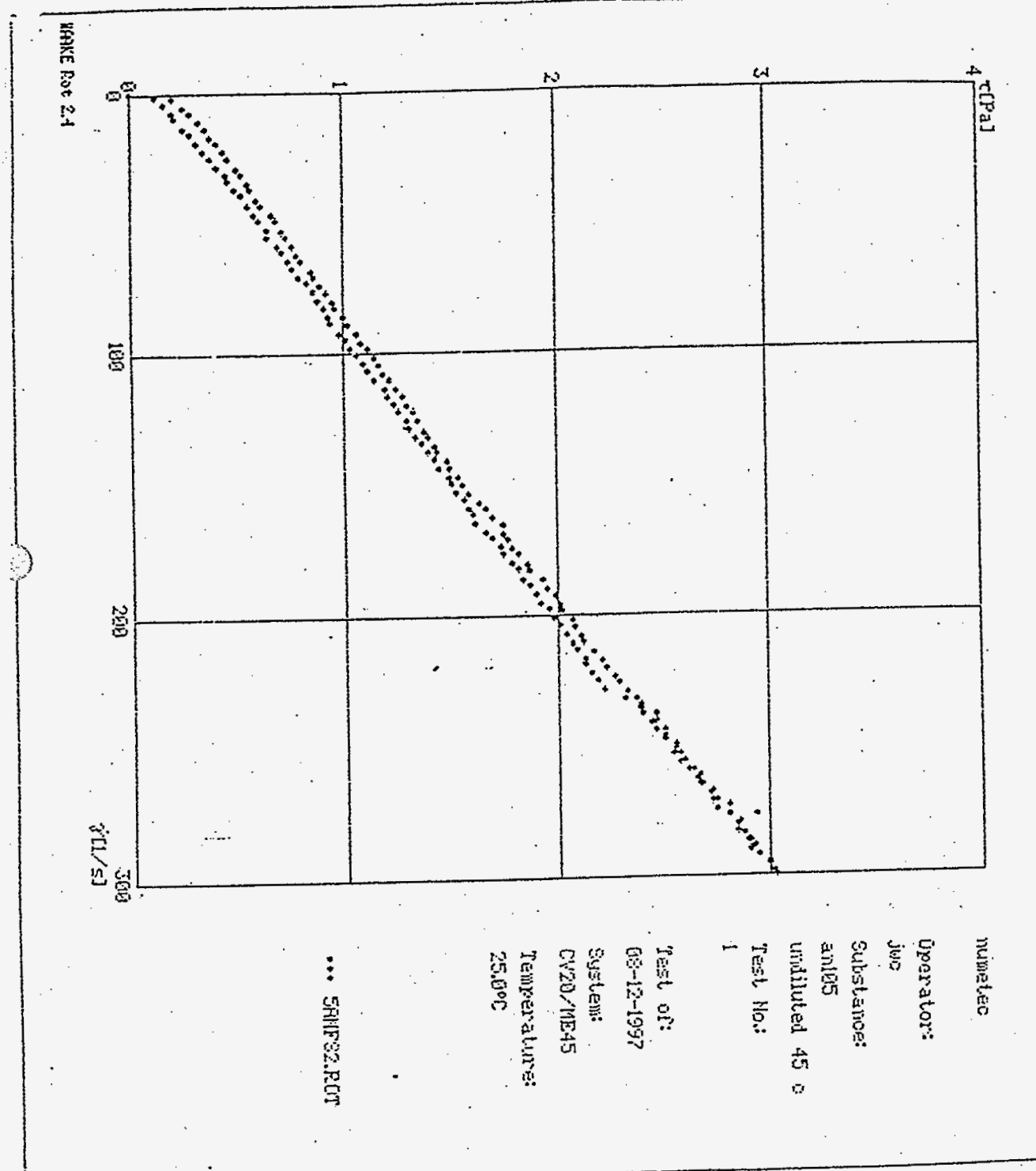




\subsection{Rheology and Waste Configuration}

In the two preceding sections we presented the results of the gas volume calculations and attempted to describe the implications and answer the "so what?" question. The last question that eventually must be answered is, "Why?". Why was the GRE behavior of SY-101 so much more severe than in the other tanks? Why does AN-103 store so much gas with hardly detectable GREs? Generally, how can we explain the gas retention and release behavior of each tank? As yet there is no satisfactory answers to these questions, but there are a few clues in the rheology and the physical condition of the waste.

The waste yield stress affects the way bubbles grow and how much is stored (Gauglitz et a1. 1996). The apparent viscosity should also have some effect on the dynamics of a GRE. However, the apparent viscosity profiles presented in Section 4 are all very similar (note that first pass apparent viscosity for $S Y-103$ was obtained at $3 \mathrm{~cm} / \mathrm{s}$ ). There are as many variations among risers in a tank as there are among different tanks. The yield stress profiles are shown in Figure 5.8. Except for AN-103 and the lower portion of SY-103, the estimated yield stress profiles are equivalent within their uncertainty.

Waste density is another indicator of GRE behavior. The ratio of supernatant to nonconvective layer densities determines the void fraction at neutral buoyancy where a rollover is possible. Density profiles of the convective layer and the nonconvective layer density are shown for all tanks in Figure 5.9 (SY-101 values are pre-mixer pump recommendations of Reynolds 1993). SY-1.01 and AN-103 have higher convective layer densities and much higher nonconvective layer densities than the others.

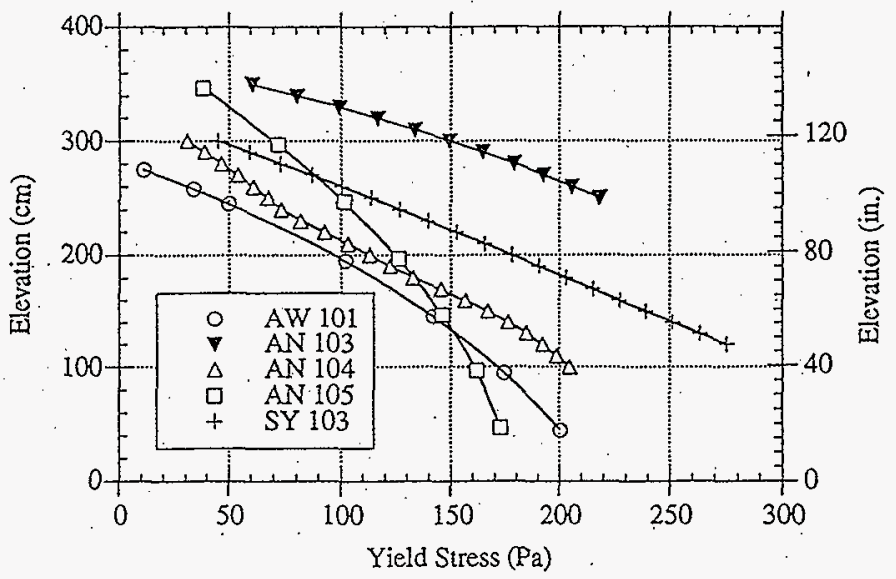

Figure 5.8. Yield Stress for Five Tanks 


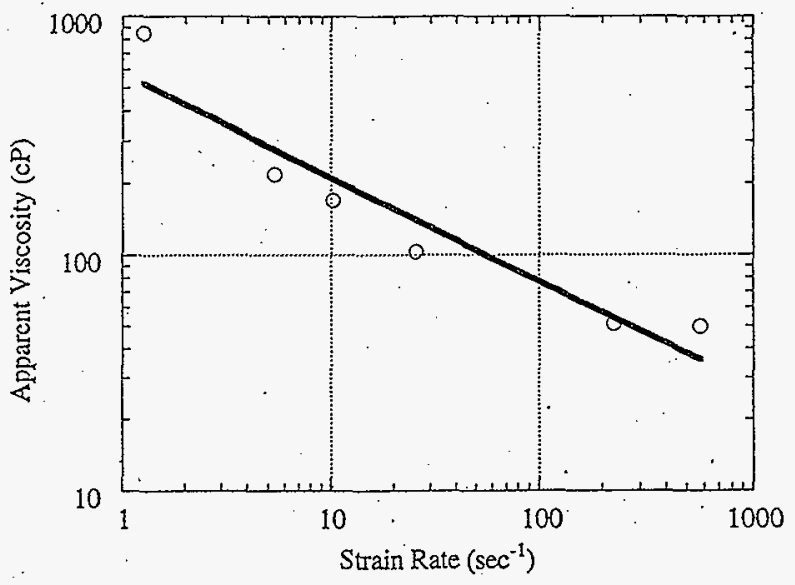

Figure 4.1.4. Apparent Viscosity of SY-101 Mixed Slurry

The ball was able to penetrate to within about $15 \mathrm{~cm}$ (approximately $6 \mathrm{in}$.) of the bottom of the tank in riser $4 \mathrm{~A}$. The material near the bottom showed shear-thickening behayior, with a very small yield stress of about $20 \mathrm{~Pa}(0.004 \mathrm{psi})$ and an average viscosity of about $20,000 \mathrm{cP}$. The yield strength profile is plotted in Figure 4.1.5.

The density of the mixed slurry derived from ball theometer data is $1.60 \pm 0.03 \mathrm{~g} / \mathrm{cm}^{3}$. The profiles of the specific gravity for the runs in $4 \mathrm{~A}$ and $11 \mathrm{~B}$ are shown in Figure 4.1.6. The data from riser $4 \mathrm{~A}$ were obtained four days after a pump run; those from riser $11 \mathrm{~B}$ were obtained just one day after a pump run. The difference in the profiles is clearly an effect of the different amounts of time availabie for solids to settle out in each case. Prior to mixing, Reynolds (1993) recommended a density of $1.57 \pm 0.04 \mathrm{~g} / \mathrm{cm}^{3}$ for the convective layer and $1.70 \pm 0.04 \mathrm{~g} / \mathrm{cm}^{3}$ for the nonconvective layer based on core samples following gas release Event $E$ in December 1991 . (Herting et al. 1992).

\subsubsection{Void Fraction and Gas Volume}

All of the void fraction measurements in SY-101 are plotted in Figure 4.1.7 along with the selected layers used to compute the average void fraction. Table 4.4 contains the average void fraction and gas volumes. Adding up the stored gas volumes in each of the three layers yields a total of $218 \pm 53 \mathrm{~m}^{3} \cdot(7,700 \pm 1,900 \mathrm{SCF})$ of gas at $1 \mathrm{~atm}$. Given the waste level of $1019 \mathrm{~cm}$ (401 in.) when the VFI measurements were made, the degassed waste level would be $1010 \mathrm{~cm}$ (398 in.), not including the gas in the crust or in the mixed slurry above $200 \mathrm{~cm}$. The computed barometric pressure response of the total in situ gas volume is $-0.32 \mathrm{~cm} / \mathrm{kPa}$, and the effective piessure for compressibility is $1.23 \mathrm{~atm}$. 
Revision 0

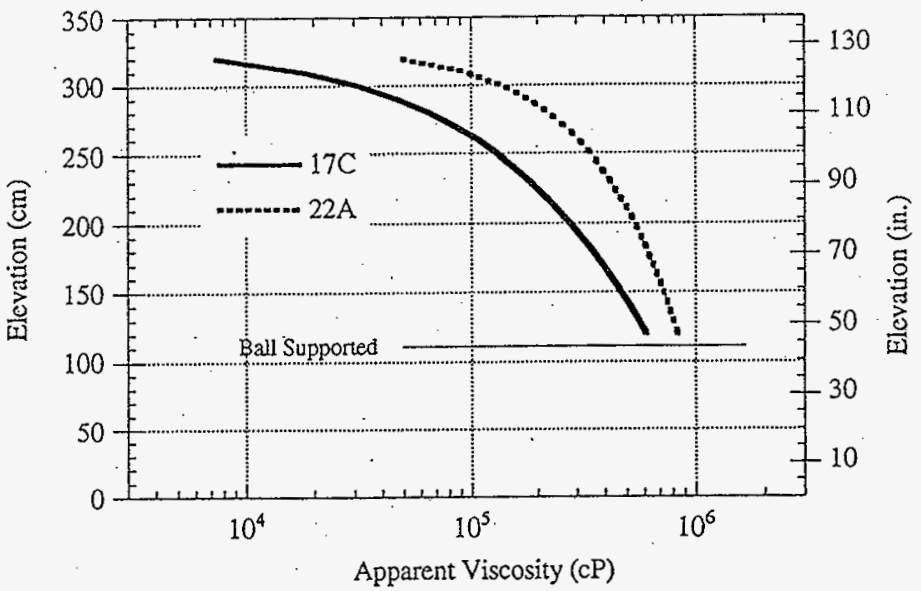

Figure 4.2.4. Apparent Viscosities in Risers $17 \mathrm{C}$ and 22A

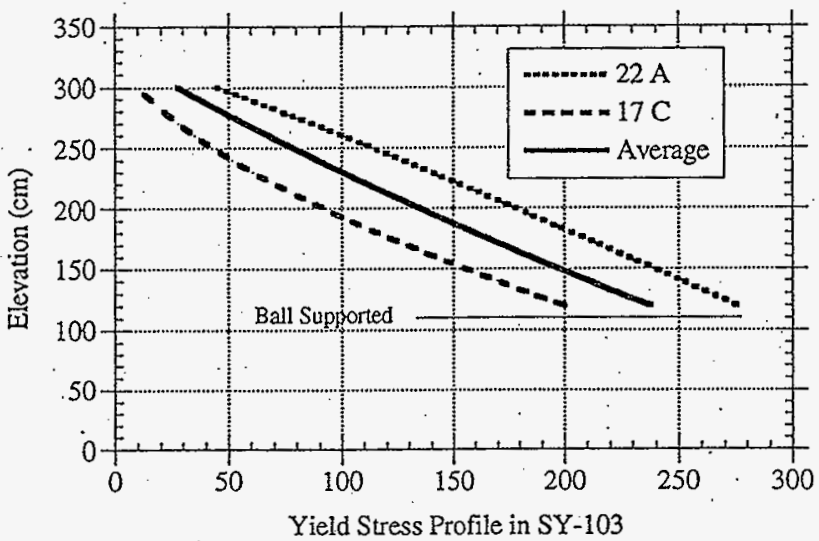

Figure 4.2.5. Yield Stress Profile in SY-103 
Revision 0

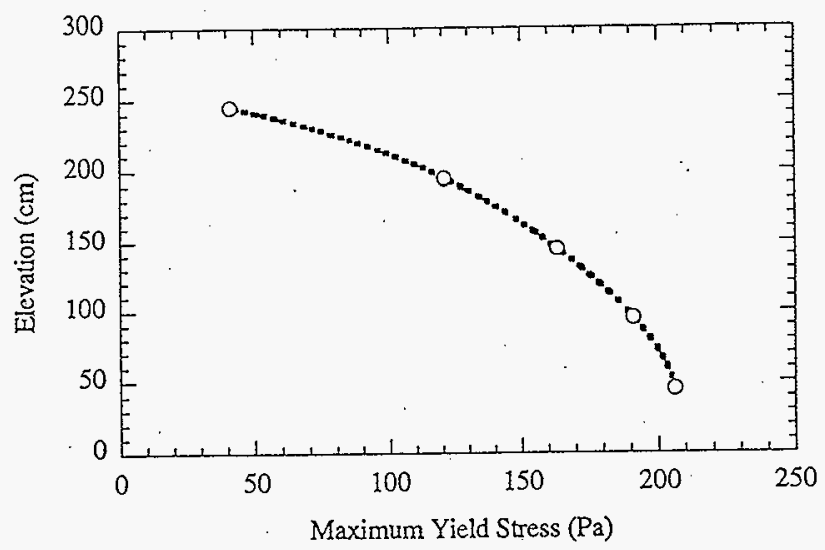

Figure 4.3.7. Upper Bound on the Yield Stress

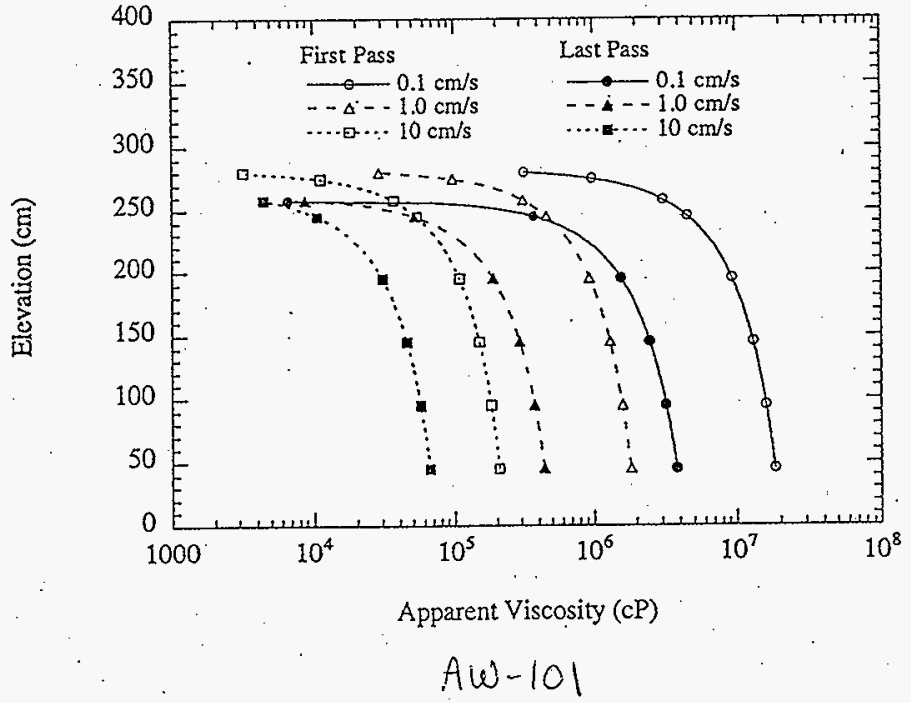

Figure 4.3.8. Apparent Viscosities of the First and Last Passes 
TWR-2244

Revision 0

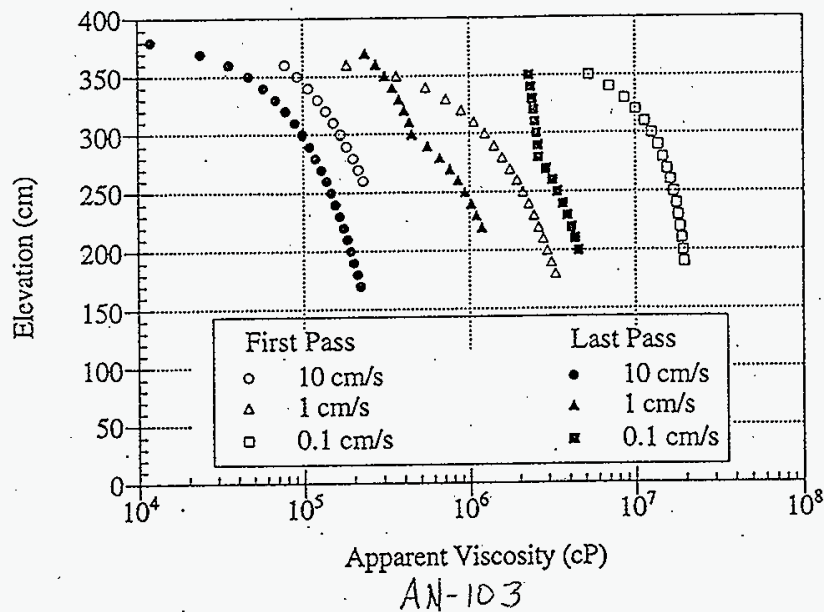

Figure 4.4.4. Apparent Viscosities in Riser 1B

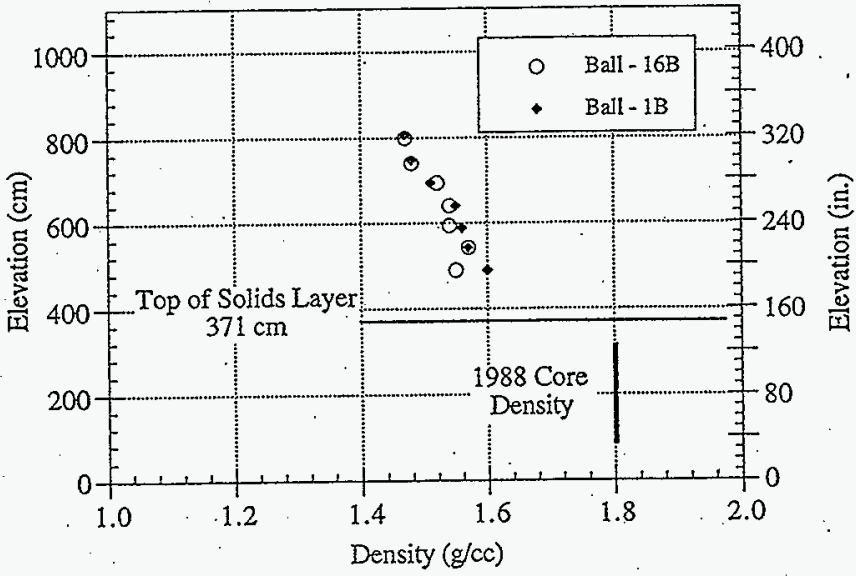

Figure 4.4.5. Density as a Function of Elevation 
Revision 0

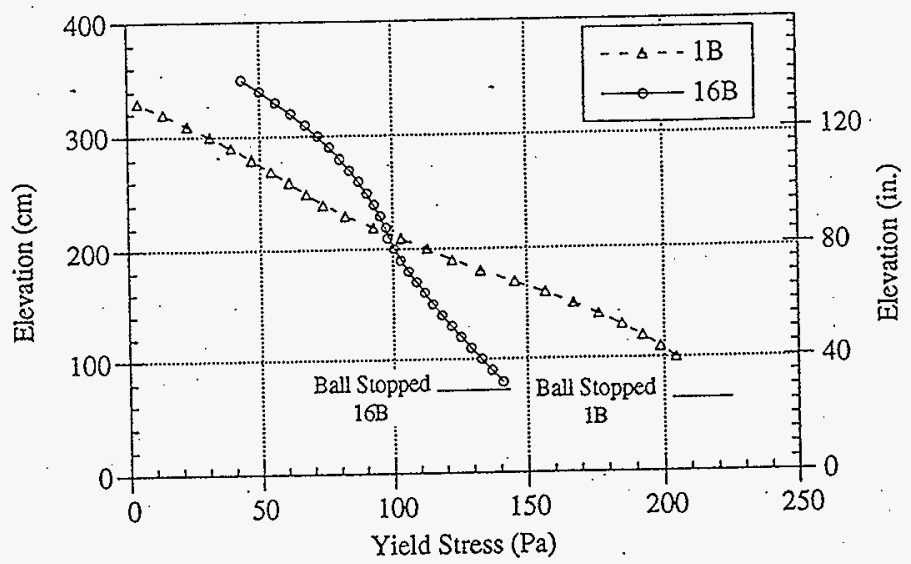

Figure 4.5.4. Upper Bound on the Yield Stress

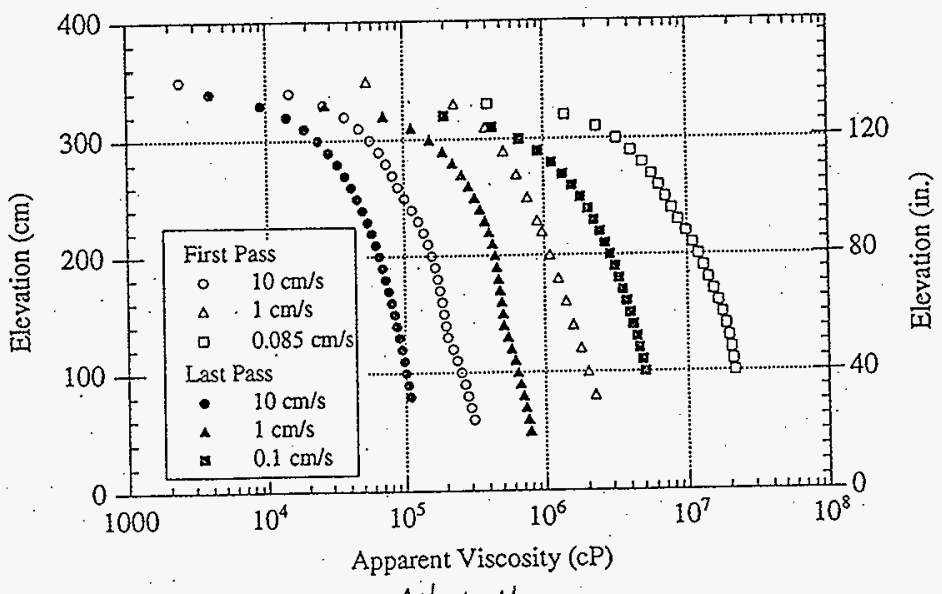

$A N-104$
Figure 4.5.5. Apparent Viscosties at.Three Strain Rates 


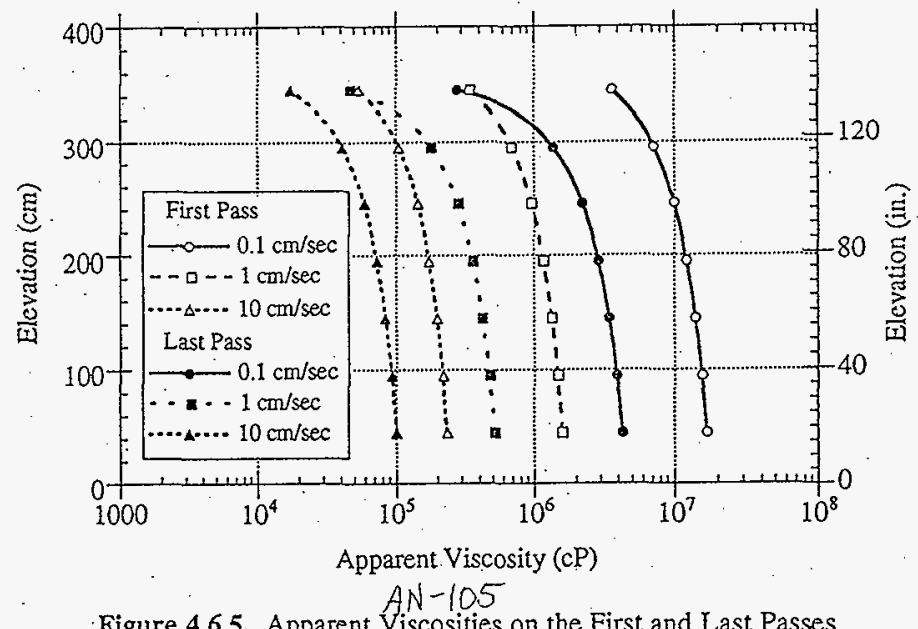

Figure 4.6.5. Apparent Viscosities on the First and Last Passes

The effective pressure ratio in the nonconvective layer is $2.08 \pm 0.03 \mathrm{~atm}$ and $1.7 \pm 0.13$ atm for the entire tank gas content. The computed barometric pressure response or compressibility is $-0.16 \pm 0.06 \mathrm{~cm} / \mathrm{kPa}$, and the effective pressure for calculating the gas volume from the barometric response correlation is $1.6 \pm 0.7 \mathrm{~atm}$.

\subsubsection{Gas Release}

The character of GREs in AN-105 shares some of the features of both SY-103 (Shepard et al. 1995) and AW-101. The initial level drop is quite rapid, as is the gas release, although the total level drop typically requires several days. The typical drop is $4 \mathrm{~cm}$ or less. The largest recent level drop, $5.9 \mathrm{~cm}$, occurred November 15, 1991. The maximum one-day drop was $6.1 \mathrm{~cm}$ on August 11, 1986. As mentioned in the introduction to this section, AN-105 experienced a $31 / 2$ year hiatus in gas releases between January 1988 and July 1991.

A relatively large release occurred August 1995. The $3.6-\mathrm{cm}$ drop indicates a $33.2 \mathrm{~m}^{3}$ (1170 SCF) total release volume. Recently installed monitoring showed the hydrogen concentration peaked at just over $1.6 \%$. This implies that about $16.8 \mathrm{~m}^{3}$ (592 SCF) of hydrogen was released into the $1066-\mathrm{m}^{3}\left(38,000-\mathrm{ft}^{3}\right)$ dome space, assuming instantaneous mixing without. ventilation. The $3.6 \mathrm{~cm}\left(1.4\right.$-in.) level drop indicates a total release of $30.8 \mathrm{~m}^{3}(1,090 \mathrm{SCF})$ if the gas is held at an effective pressure ratio of 2.08 . Dividing the estimated hydrogen release by the total release volume implies that the gas contains about 54\% hydrogen, which is consistent with recent preliminary data from the RGS. ${ }^{\left({ }^{3}\right)}$ No significant temperature changes were observed in the

(a) Personal communication of preliminary data by JM Bates, PNNL, August 1996. 
TWR-2244

Revision 0

This page intentionally left blank. 


\section{DISTRIBUTION SHEET}

\begin{tabular}{|c|c|c|c|c|c|}
\hline \multirow{2}{*}{$\begin{array}{l}\text { To } \\
\text { Distribution }\end{array}$} & \multirow{2}{*}{\multicolumn{3}{|c|}{$\begin{array}{l}\text { From } \\
\text { B. B. Peters/T. W. Crawford }\end{array}$}} & \multicolumn{2}{|l|}{ Page 1 of 1} \\
\hline & & & & \multicolumn{2}{|c|}{ Date $2 / 11 / 98$} \\
\hline \multirow{2}{*}{\multicolumn{4}{|c|}{$\begin{array}{l}\text { Project Title/Work Order } \\
\text { Retrieved Waste Properties and High-Level Waste Critical } \\
\text { Component Ratios for Privatization Waste Feed Delivery, } \\
\text { TWR-2244, Rev. } 0\end{array}$}} & \multicolumn{2}{|c|}{ EDT No. 622705} \\
\hline & & & & \multicolumn{2}{|l|}{ ECN No. } \\
\hline \multicolumn{2}{|l|}{ Name } & $\begin{array}{l}\text { Text } \\
\text { With All } \\
\text { Attach. }\end{array}$ & Text Only & $\begin{array}{l}\text { Attach./ } \\
\text { Appendix } \\
\text { Only }\end{array}$ & $\begin{array}{l}\text { EDT/ECN } \\
\text { Only }\end{array}$ \\
\hline $\begin{array}{l}\text { Centra1 Files } \\
\text { DOE Reading Room }\end{array}$ & \multicolumn{2}{|r|}{$\begin{array}{l}X \\
X\end{array}$} & & \\
\hline $\begin{array}{l}\text { S. K. Baker } \\
\text { P. J. Certa } \\
\text { A. F. Choho } \\
\text { R. D. Claghorn } \\
\text { T. J. Conrads } \\
\text { T. W. Crawford } \\
\text { M. A. Delamare } \\
\text { J. S. Garfield } \\
\text { C. E. Grenard } \\
\text { R. P. Marsha11 } \\
\text { S. M. 0 Toole } \\
\text { I. G. Papp } \\
\text { B. B. Peters } \\
\text { R. W. Powell } \\
\text { R. L. Treat }\end{array}$ & $\begin{array}{l}H 5-49 \\
H 5-61 \\
H 6-35 \\
H 5-49 \\
H 5-25 \\
H 5-49 \\
H 5-61 \\
H 5-49 \\
H 5-61 \\
H 5-61 \\
G 3-21 \\
H 5-49 \\
H 5-03 \\
H 5-03 \\
H 5-03\end{array}$ & $\begin{array}{l}X \\
X \\
X \\
X \\
X \\
X \\
X \\
X \\
X \\
X \\
X \\
X \\
X \\
X \\
X\end{array}$ & & . & \\
\hline TWR CPF \#28 & H6-08 & $\times(1$ & & \\
\hline
\end{tabular}

